\title{
BABAM2 wt Allele
}

National Cancer Institute

\section{Source}

National Cancer Institute. BABAM2 wt Allele. NCI Thesaurus. Code C124105.

Human BABAM2 wild-type allele is located in the vicinity of 2p23.2 and is approximately $449 \mathrm{~kb}$ in length. This allele, which encodes BRISC and BRCA1-A complex member 2 protein, plays a role in the recognition of damaged DNA. 